\title{
Photoinhibition of Leaves with Different Photosynthetic Carbon Assimilation Characteristics in Maize (Zea mays)
}

\author{
Yanye Ruan1,2, Xiaoyang Li1, Yanpeng Wang1, Siqi Jiang1, Bo Song3, Zhiyou Guo ${ }^{3}$, Ao Zhang1, \\ Qi Qi1, Lijun Zhang1,2, Jinjuan Fan1,2, Yixin Guan4, Zhenhai Cui ${ }^{1,2 *}$, Yanshu Zhu ${ }^{1,2 *}$ \\ ${ }^{1}$ Biological Science and Technology College, Shenyang Agricultural University, Shenyang, China \\ ${ }^{2}$ Liaoning Province Research Center of Plant Genetic Engineering Technology, Shenyang, China \\ ${ }^{3}$ Test Site of Shenyang Agricultural University, Shenyang, China \\ ${ }^{4}$ Northeast Institute of Geography and Agroecology, Chinese Academy of Sciences, Changchun, China \\ Email: *cuizhenhai1978@163.com, *zhu-yanshu@163.com
}

How to cite this paper: Ruan, Y.Y., Li, X.Y., Wang, Y.P., Jiang, S.Q., Song, B., Guo, Z.Y., Zhang, A., Qi, Q., Zhang, L.J., Fan, J.J., Guan, Y.X., Cui, Z.H. and Zhu, Y.S. (2017) Photoinhibition of Leaves with Different Photosynthetic Carbon Assimilation Characteristics in Maize (Zea mays). American Journal of Plant Sciences, 8, 328-339. https://doi.org/10.4236/ajps.2017.83023

Received: December 3, 2016

Accepted: February 1, 2017

Published: February 4, 2017

Copyright (c) 2017 by authors and Scientific Research Publishing Inc. This work is licensed under the Creative Commons Attribution International License (CC BY 4.0).

http://creativecommons.org/licenses/by/4.0/

\begin{abstract}
Strong light decreases the rate of photosynthesis and assimilates production of crop plants. Plants with different carbon reduction cycles respond differently to strong light stress. However, variation in photoinhibition in leaves with different photosynthetic characteristics in maize is not clear. In this experiment, we used the first leaves (with an incomplete $\mathrm{C}_{4}$ cycle) and fifth leaves (with a complete $\mathrm{C}_{4}$ cycle) of maize plants as well as the fifth leaves $\left(\mathrm{C}_{3}\right.$ cycle) of tobacco plants as a reference to measure the photosynthetic rate $\left(\mathrm{P}_{\mathrm{N}}\right)$ and chlorophyll a parameters under strong light stress. During treatment, $\mathrm{P}_{\mathrm{N}}$, the maximal fluorescence $\left(\mathrm{F}_{\mathrm{m}}\right)$, the maximal quantum yield of PSII photochemistry $\left(\mathrm{F}_{\mathrm{v}} / \mathrm{F}_{\mathrm{m}}\right)$, and the number of active photosystem II (PSII) reaction centers per excited cross-section $\left(\mathrm{RC} / \mathrm{CS}_{\mathrm{m}}\right)$ declined dramatically in all three types of leaves but to different degrees. $\mathrm{P}_{\mathrm{N}}, \mathrm{F}_{\mathrm{m}}, \mathrm{F}_{\mathrm{v}} / \mathrm{F}_{\mathrm{m}}$, and $\mathrm{RC} / \mathrm{CS}_{\mathrm{m}}$ were less inhibited by strong light in $\mathrm{C}_{4}$ leaves. The results showed that maize $\mathrm{C}_{4}$ leaves with higher rates of photosynthesis are more tolerant to strong light stress than incomplete $\mathrm{C}_{4}$ leaves, and the carbon reduction cycle is more important to photoprotection in $\mathrm{C}_{4}$ leaves, while state transition is critical in incomplete $\mathrm{C}_{4}$ leaves.
\end{abstract}

\section{Keywords}

Fluorescence Transient, Photosystem II (PSII), Photoprotection, Light Stress, $\mathrm{C}_{4}$ Photosynthesis

\section{Introduction}

Strong light is an important factor that reduces photosynthetic activity and lim- 
its the production of assimilates in crop plants via a process called photoinhibition [1]. The longer the exposure to excess excitation energy, the more damage to the photosynthetic apparatus. To avoid this damage, plants have evolved a series of protective mechanisms [2] [3] [4] [5], including photochemical quenching, fluorescence quenching, and thermal dissipation of excess excitation energy. Photochemical quenching is related to the activity of photosystem II (PSII) reaction centers (RC), the efficiency of the electron transfer chain, and the capacity of the photosynthetic carbon cycle. As the terminal destination of excitation energy, the photosynthetic cycle affects the amount of surplus excitation energy absorbed by leaves.

Based on the pathway of photosynthetic carbon fixation, higher plants are classified into three types: $\mathrm{C}_{3}, \mathrm{C}_{4}$, and CAM. In $\mathrm{C}_{3}$ plants, photosynthesis operates in mesophyll cells (MC) via PSII and ribulose bisphosphate carboxylase/ oxygenase (Rubisco). $\mathrm{C}_{4}$ plants evolved from $\mathrm{C}_{3}$ plants [6] and have a higher carbon reduction efficiency. In typical $\mathrm{C}_{4}$ plants, $\mathrm{MC}$ and vascular bundle sheath cells (BSC) in the leaves are arranged in specialized Kranz anatomy around vascular tissues. MC chloroplasts have higher PSII activity and lower Rubisco activity. In contrast, BSC chloroplasts have lower PSII activity and higher Rubisco activity [7] [8]. Additionally, $\mathrm{C}_{4}$ photosynthetic enzymes are distributed in $\mathrm{MC}$ and BSC, which cooperate during $\mathrm{C}_{4}$ photosynthesis.

The responses of plants with different photosynthetic pathways to strong light are different [9] [10] [11]. $\mathrm{C}_{4}$ plants are less susceptible to strong light stress than $\mathrm{C}_{3}$ plants [10]. The maximal photochemical efficiency of PSII $\left(\mathrm{F}_{\mathrm{v}} / \mathrm{F}_{\mathrm{m}}\right)$ declined more slowly in $\mathrm{C}_{4}$ maize than that in $\mathrm{C}_{3}$ plants under strong light [12], while the efficiency of the $\mathrm{C}_{4}$ photosynthetic cycle varies in maize leaves at different positions. The first to third leaves of maize have not completed the differentiation of $\mathrm{MC}$ and BSC and thus have a less efficient $\mathrm{C}_{4}$ cycle, with lower activity of $\mathrm{C}_{4}$ photosynthetic enzymes in MC and higher activity of PSII in BSC [13] [14]. However, how these maize leaves differ in photoinhibition is not clear. Knowing this difference and its cause would help to understand the mechanisms of strong light defense in plants. In this paper, we investigated the differences in photoinhibition among the first (incomplete $\mathrm{C}_{4}$ cycle) and fifth (complete $\mathrm{C}_{4}$ cycle) leaves of maize and the fifth leaves $\left(\mathrm{C}_{3}\right.$ cycle) of the $\mathrm{C}_{3}$ plant tobacco as a reference and analyzed the basis of the differences.

\section{Materials and Methods}

\subsection{Experimental Materials}

Maize hybrid Zhengdan958 (a widely used Chinese hybrid) was crossed by Zheng58 and Chang7-2 inbred at Experimental Station of Shenyang Agricultrual University in the summer of 2012. Tobacco K326 were from plant immunity institute of Shenyang Agricultrual University. Both maize and tobacco were grown in pots in a growth chamber. The photon flux density (PFD) on the plant canopy was $1000 \mu \mathrm{mol} \cdot \mathrm{m}^{-2} \cdot \mathrm{s}^{-1}$ from metal halogen lamps with a $14 \mathrm{~h} / 10 \mathrm{~h}$ light/dark cycle at $24^{\circ} \mathrm{C} / 22^{\circ} \mathrm{C}$ (day/night). The first (M1) and fifth (M5) fully expanded 
leaves on maize plants and the fifth (T5) fully expanded leaves on tobacco were used for measurements.

\subsection{Treatments}

Plants were illuminated for $3 \mathrm{~h}$ at $28^{\circ} \mathrm{C}$ and a PFD of $2000 \mu \mathrm{mol} \cdot \mathrm{m}^{-2} \cdot \mathrm{s}^{-1}$ as a strong light treatment. A distance of $0.5 \mathrm{~m}$ above the top of plant were measured. The white light source was $400 \mathrm{~W}$ SON-T AGRO lamps (Royal Dutch Philips Electronics Ltd., Amsterdam, Netherlands). Each treatment was repeated with six plants.

\subsection{Photosynthetic Rate}

Photosynthetic rate $\left(\mathrm{P}_{\mathrm{N}}\right)$ was measured each hour during the light treatment using a potable photosynthesis system (CIRAS-1, PP-system, Hitchin, UK) in normal air from 8:00 am to 11:00 am.

\subsection{Photorespiration Rate and Gross Photosynthetic Rate}

The $\mathrm{P}_{\mathrm{n}}$ was measured at the end of the $3 \mathrm{~h}$ light treatment using the CIRAS- 1 PP-system in normal air $\left(21 \% \mathrm{O}_{2}+75 \% \mathrm{~N}_{2}+380 \mu \mathrm{mol} \cdot \mathrm{mol} \mathrm{CO}_{2}^{-1}\right)$ and lowoxygen air $\left(2 \% \mathrm{O}_{2}+95 \% \mathrm{~N}_{2}+380 \mu \mathrm{mol} \cdot \mathrm{mol} \mathrm{CO}_{2}^{-1}\right)$. The photorespiration rate $\left(\mathrm{P}_{\mathrm{r}}\right)$ was calculated as the difference between $\mathrm{P}_{\mathrm{N}}$ in low-oxygen and normal air, using the equation $\left(\mathrm{Pn} 2 \% \mathrm{O}_{2}-\mathrm{Pn} 21 \% \mathrm{O}_{2}\right) / \mathrm{Pn} 2 \% \mathrm{O}_{2}[15]$. The $\mathrm{P}_{\mathrm{N}}$ in low-oxygen air was designated the gross photosynthetic rate $\left(\mathrm{GP}_{\mathrm{N}}\right)$.

\subsection{Chlorophyll $a$ Fluorescence Parameters}

We measured chlorophyll a fluorescence each hour during the light treatment with a Hand-PEA (Hansatech Instruments Limited, UK). After 20 min of dark adaptation, all sample leaves were immediately exposed to a saturating light pulse $\left(3000 \mu \mathrm{mol} \cdot \mathrm{m}^{-2} \cdot \mathrm{s}^{-1}\right)$ for $2 \mathrm{~s}$. The fluorescence transients in each darkadapted leaf were analyzed according to the JIP-test using the following parameters: 1) the initial fluorescence $\left.\left(\mathrm{F}_{0}\right) ; 2\right)$ the maximal fluorescence $\left.\left(\mathrm{F}_{\mathrm{m}}\right) ; 3\right)$ the difference between $\mathrm{F}_{\mathrm{m}}$ and $\left.\mathrm{F}_{0}\left(\mathrm{~F}_{\mathrm{v}}\right) ; 4\right)$ the maximal quantum yield of PSII photochemistry $\left.\left(\mathrm{F}_{\mathrm{v}} / \mathrm{F}_{\mathrm{m}}\right) ; 5\right)$ the quantum yield of fluorescence dissipation $\left(\Phi \mathrm{D}_{0}\right)$; and 6) the number of active PSII RC per excited cross-section $\left(\mathrm{CS}_{\mathrm{m}}\right)$.

\subsection{Statistical Analysis}

Statistical analyses were performed using SPSS 11.5 (IBM, Chicago, IL, USA). Treatment means were subjected to two-way analysis of variance (ANOVA), and these values and their significant differences (measured by Duncan's significance test) are presented in the figures and table. Design of the experiments was completely randomized with six replications.

\section{Results}

\subsection{Photosynthesis}

The three types of leaves had different $\mathrm{P}_{\mathrm{N}}$ values under control light conditions 
and varied in their responses to the strong light treatment (Figure 1). Under control light, M5 showed the highest $\mathrm{P}_{\mathrm{N}}\left(22 \mu \mathrm{mol} \mathrm{CO} \cdot \mathrm{m}^{-2} \cdot \mathrm{s}^{-1}\right)$, followed by M1 $\left(18 \mu \mathrm{mol} \mathrm{CO} \mathrm{CO}_{2} \cdot \mathrm{m}^{-2} \cdot \mathrm{s}^{-1}\right)$ and $\mathrm{T} 5\left(14 \mu \mathrm{mol} \mathrm{CO} \mathrm{CO}_{2} \cdot \mathrm{m}^{-2} \cdot \mathrm{s}^{-1}\right)$. Under strong light, all three types of leaves showed a decrease in $\mathrm{P}_{\mathrm{N}}$, suggesting the occurrence of photoinhibition in all experimental materials. During the treatment period, $\mathrm{P}_{\mathrm{N}}$ of M5 declined slowly, by $6.8 \%$ in the first hour; M1 decreased more rapidly in the first hour (by $44.4 \%$ ) and then more slowly. A similar pattern was observed in T5, but $\mathrm{P}_{\mathrm{N}}$ decreased more sharply (by 60.7\%) in the first hour. During treatment, M5 maintained a consistently higher $\mathrm{P}_{\mathrm{N}}$ than did M1 and T5. These results suggested that $\mathrm{C}_{4}$ leaves (M5) were more tolerant to strong light stress than leaves with an incomplete $\mathrm{C}_{4}(\mathrm{M} 1)$ and $\mathrm{C}_{3}$ leaves (T5).

\subsection{Photorespiration and Gross Photosynthesis}

The three types of leaves had different $\mathrm{P}_{\mathrm{r}}$ values at the end of the 3-h strong light treatment (Table 1). T5 showed the highest $\mathrm{P}_{\mathrm{r}}\left(2.87 \mu \mathrm{mol} \mathrm{CO} \mathrm{CO}_{2} \cdot \mathrm{m}^{-2} \cdot \mathrm{s}^{-1}\right)$ and $\mathrm{P}_{\mathrm{r}} / \mathrm{GP}_{\mathrm{N}}$ ratio $(43.50 \%)$, followed by $\mathrm{M} 1\left(2.60 \mu \mathrm{mol} \mathrm{CO} \mathrm{CO}_{2} \cdot \mathrm{m}^{-2} \cdot \mathrm{s}^{-1}, 17.8 \%\right)$ and M5 $\left(0.47 \mu \mathrm{mol} \mathrm{CO} \mathrm{CO}^{-2} \cdot \mathrm{s}^{-1}, 2.24 \%\right) \cdot \mathrm{GP}_{\mathrm{N}}$, the sum of $\mathrm{P}_{\mathrm{N}}$ and $\mathrm{P}_{\mathrm{r}}$, indicates the amount

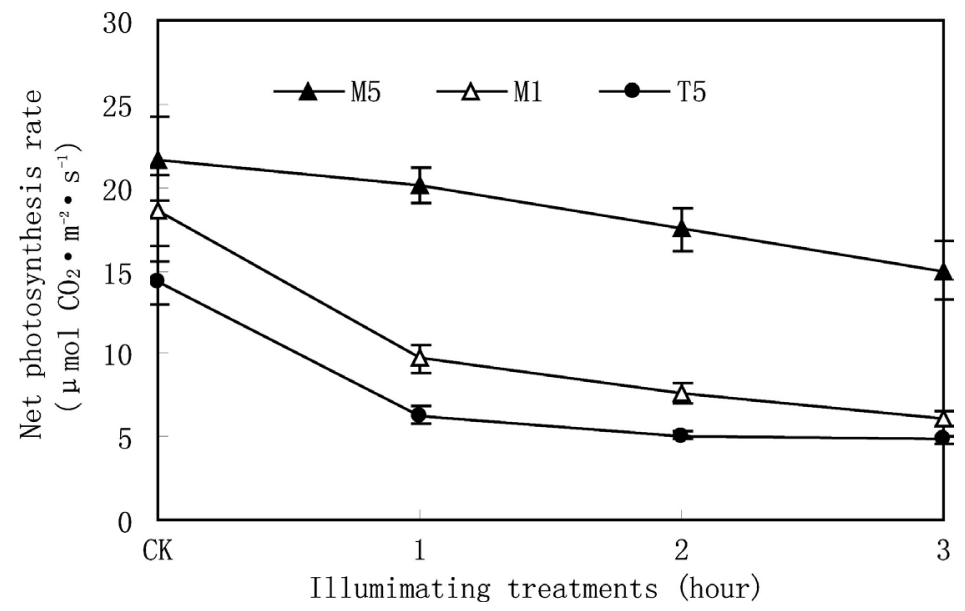

Figure 1. Changes in net photosynthesis rate $\left(\mathrm{P}_{\mathrm{n}}\right)$ in leaves with different photosynthetic characteristics during strong light treatments. The sample leaves were subjected to strong light $\left(2000 \mu \mathrm{mol} \cdot \mathrm{m}^{-2} \cdot \mathrm{s}^{-1}\right)$ for $3 \mathrm{~h}$. $\boldsymbol{\Delta}$, maize fifth leaves (complete $\mathrm{C}_{4}$ cycle, M5); $\triangle$, maize first leaves (incomplete $\mathrm{C}_{4}$ cycle, $\mathrm{M1}$ ); $\bullet$, tobacco fifth leaves $\left(\mathrm{C}_{3}\right.$ cycle, T5). Mean $\pm \mathrm{SD}$ of six replicates. Bars not seen are smaller than the size of the symbols.

Table 1. Photorespiration rates of leaves with different types of photosynthesis under strong light treatment.

\begin{tabular}{ccccc}
\hline Materials & $\begin{array}{c}\text { Gross photosynthetic rate }\left(\mathrm{GP}_{\mathrm{n}}\right) \\
\text { in } 2 \% \mathrm{O}_{2}\left(\mu \mathrm{mol} \mathrm{CO} \mathrm{C}_{2} \cdot \mathrm{m}^{-2} \cdot \mathrm{s}^{-1}\right)\end{array}$ & $\begin{array}{c}\text { Net photosynthetic rate }\left(\mathrm{P}_{\mathrm{n}}\right) \\
\text { in } 21 \% \mathrm{O}_{2}\left(\mu \mathrm{mol} \mathrm{CO} \mathrm{CO}_{2} \cdot \mathrm{m}^{-2} \cdot \mathrm{s}^{-1}\right)\end{array}$ & $\begin{array}{c}\text { Photorespiration rate }\left(\mathrm{P}_{\mathrm{r}}\right) \\
\left(\mu \mathrm{mol} \mathrm{CO}_{2} \cdot \mathrm{m}^{-2} \cdot \mathrm{s}^{-1}\right)\end{array}$ & $\begin{array}{c}\mathrm{P}_{\mathrm{r}} \text { in } 21 \% \mathrm{O}_{2} / \mathrm{GP}_{\mathrm{n}} \\
\text { in } 2 \% \mathrm{O}_{2}(\%)\end{array}$ \\
\hline Maize fifth leaves (M5) & $20.73 \pm 0.15 \mathrm{a}$ & $20.27 \pm 0.32 \mathrm{a}$ & $0.47 \pm 0.06 \mathrm{~b}$ & $2.24 \mathrm{c}$ \\
Maize first leaves (M1) & $14.57 \pm 0.32 \mathrm{~b}$ & $11.97 \pm 0.21 \mathrm{~b}$ & $2.60 \pm 0.22 \mathrm{a}$ & $17.80 \mathrm{~b}$ \\
Tobacco leaves (T5) & $6.57 \pm 0.20 \mathrm{c}$ & $3.70 \pm 0.23 \mathrm{c}$ & $2.87 \pm 0.33 \mathrm{a}$ & $43.50 \mathrm{a}$ \\
\hline
\end{tabular}

Note: Sample leaves were subjected to strong light $\left(2000 \mu \mathrm{mol} \cdot \mathrm{m}^{-2} \cdot \mathrm{s}^{-1}\right)$ for $3 \mathrm{~h}$ and measured at the end of the light treatment. Each value in the table represents mean $\pm \mathrm{SD}$ of six leaves. Maize fifth leaves have a complete $\mathrm{C}_{4}$ cycle (M5), maize first leaves have an incomplete $\mathrm{C}_{4}$ cycle (M1), and tobacco fifth leaves have a $\mathrm{C}_{3}$ cycle (T5). Different letters above each column indicate significant differences at $\mathrm{P}<0.01$ (measured by Duncan's significance test). Values are means \pm S.D. $(n=6)$. 
of energy consumed via carbon reduction and the oxidation cycle in plants. Similar to the pattern seen with $\mathrm{P}_{\mathrm{N}}$, at the end of the treatment, M5 had the highest $\mathrm{GP}_{\mathrm{N}}\left(20.73 \mu \mathrm{mol} \mathrm{CO} \cdot \mathrm{m}^{-2} \cdot \mathrm{s}^{-1}\right)$, followed by M1 $\left(14.57 \mu \mathrm{mol} \mathrm{CO}{ }_{2} \cdot \mathrm{m}^{-2} \cdot \mathrm{s}^{-1}\right)$ and T5 $\left(6.57 \mu \mathrm{mol} \mathrm{CO} \mathrm{CO}_{2} \cdot \mathrm{m}^{-2} \cdot \mathrm{s}^{-1}\right)$. Despite the higher $\mathrm{P}_{\mathrm{r}}$ and $\mathrm{P}_{\mathrm{r}} / \mathrm{GP}_{\mathrm{N}}$ under strong light stress, $\mathrm{GP}_{\mathrm{N}}$ in the $\mathrm{C}_{3}$ leaves (T5) and incomplete $\mathrm{C}_{4}$ leaves (M1) was still lower than that in the $\mathrm{C}_{4}$ leaves (M5).

\section{3. $\mathrm{F}_{0}, \mathrm{~F}_{\mathrm{m}}$, and $\mathrm{F}_{\mathrm{v}}$}

$\mathrm{F}_{0}$ is measured when the PSII RC are completely open and represents the intrinsic loss of energy transfer from chlorophyll a to the RC in PSII. As shown in Figure 2(a), under control light, $M 1$ showed the highest $\mathrm{F}_{0}$ (251.33), followed by T5 (228.00) and M5 (181.67); all types of leaves experienced a slow decrease in $\mathrm{F}_{0}$ under strong light. This experiment showed that $\mathrm{F}_{0}$ was not very susceptible to strong light stress.

$\mathrm{F}_{\mathrm{m}}$ is measured when the RC of PSII are totally closed and represents the maximal amount of energy absorbed by chlorophyll a in PSII. As shown in Figure 2(b), under control light, $T 5$ showed the highest $F_{m}$ (1355.00), followed by M1 (1116.00) and M5 (795.67). Under strong light, $F_{m}$ in all types of leaves decreased sharply in the first hour, by $49.77 \%$ (to 399.67 ) in M5, by $63.26 \%$ (to 410.00) in M1, and by $55.11 \%$ (to 608.25) in T5. The decline then slowed in M5 and $\mathrm{M} 1$ but continued rapidly in $\mathrm{T} 5$. The data demonstrated that $\mathrm{F}_{\mathrm{m}}$ in all three types of leaves was susceptible to strong light stress, but $\mathrm{C}_{4}$ leaves (M5) were less vulnerable than incomplete $\mathrm{C}_{4}$ leaves (M1) and $\mathrm{C}_{3}$ leaves (T5).

$F_{v}$ is the difference between $F_{m}$ and $F_{0}$ and indicates the maximal amount of energy used by PSII photochemical reactions. Generally, the $\mathrm{C}_{4}$ cycle has the highest capacity of excitation energy use among the three types of photosynthetic carbon reduction pathways. In this experiment (Figure 2(c)), under control light, T5 showed the highest $F_{v}$ (1127.00), followed by M1 (864.67) and M5 (614.00). The pattern was similar to that of $F_{m}$ under strong light. $F_{v}$ in all types of leaves decreased sharply in the first hour, to 250.50 (by 59.20\%) in M5, to 172.5 (by $80.05 \%$ ) in $\mathrm{M} 1$, and to 186.33 (by $83.47 \%$ ) in $\mathrm{T} 5$, and then more slowly, suggesting that $\mathrm{F}_{\mathrm{v}}$ in $\mathrm{C}_{4}$ leaves (M5) was less vulnerable to strong light stress than in incomplete $\mathrm{C}_{4}$ leaves (M1) and $\mathrm{C}_{3}$ leaves (T5). The decline in $\mathrm{F}_{\mathrm{v}}$ was mainly caused by changes in $\mathrm{F}_{\mathrm{m}}$.

\section{4. $\mathrm{F}_{\mathrm{v}} / \mathrm{F}_{\mathrm{m}}$ and $\Phi \mathrm{D}_{0}$}

$\mathrm{F}_{\mathrm{v}} / \mathrm{F}_{\mathrm{m}}$ describes the efficiency of the PSII photochemical reaction. As shown in Figure 2(d), under control light, the value of $F_{v} / F_{m}$ was 0.771 in M5, 0.775 in M1 and 0.832 in T5. Under strong light, $F_{v} / F_{m}$ of all sample leaves declined sharply, but less so in M5, which reached its lowest value (0.531) in the second hour, than in M1 and T5, which reached their lowest values ( 0.221 and 0.173 , respectively) in the third hour. Thus, in $\mathrm{F}_{\mathrm{v}} / \mathrm{F}_{\mathrm{m}}$, M5 was more tolerant to light stress than M1 and T5. The decline of $F_{v} / F_{m}$ in all types of leaves was attributed to the decrease in $\mathrm{F}_{\mathrm{m}}$. 


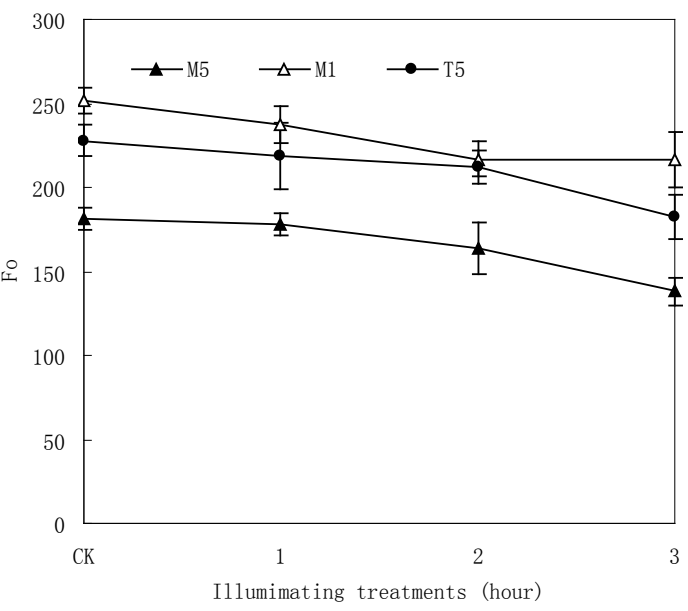

(a)

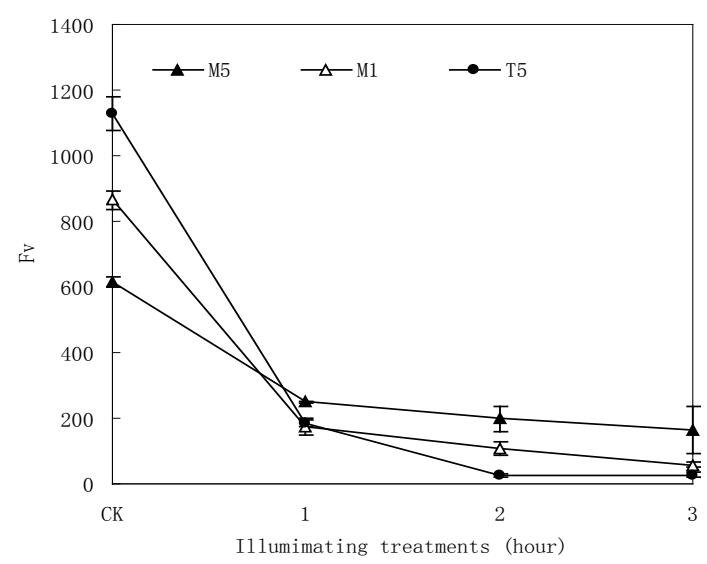

(c)

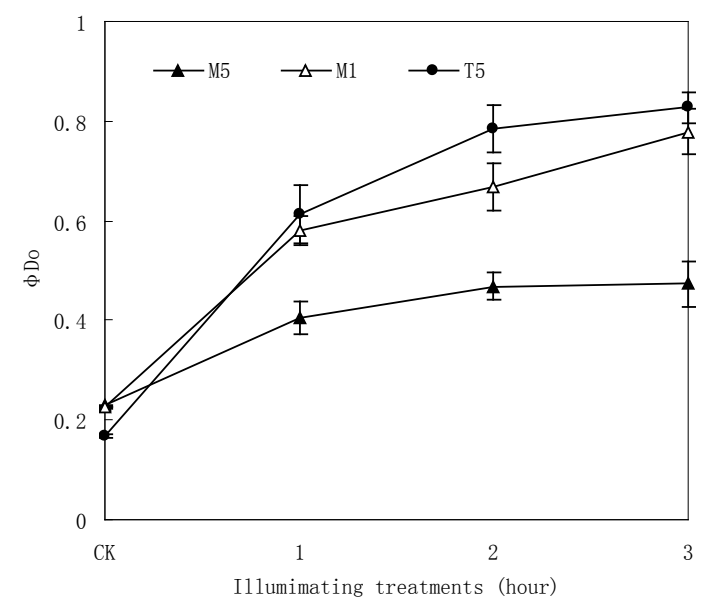

(e)

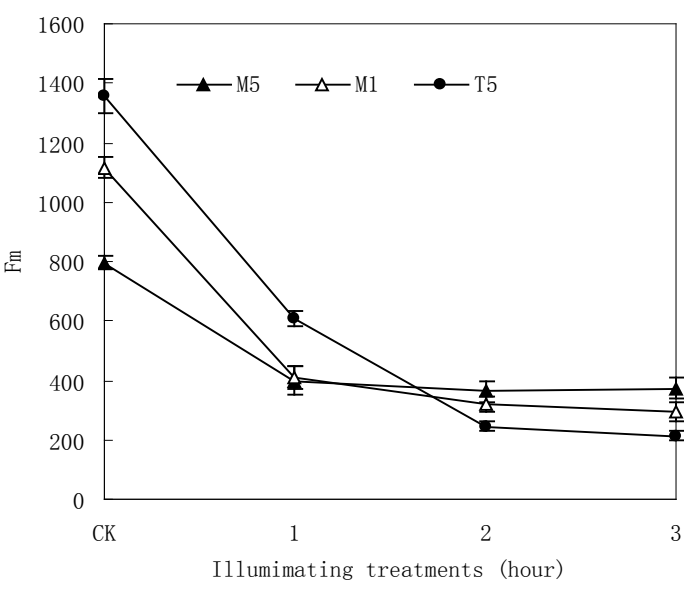

(b)

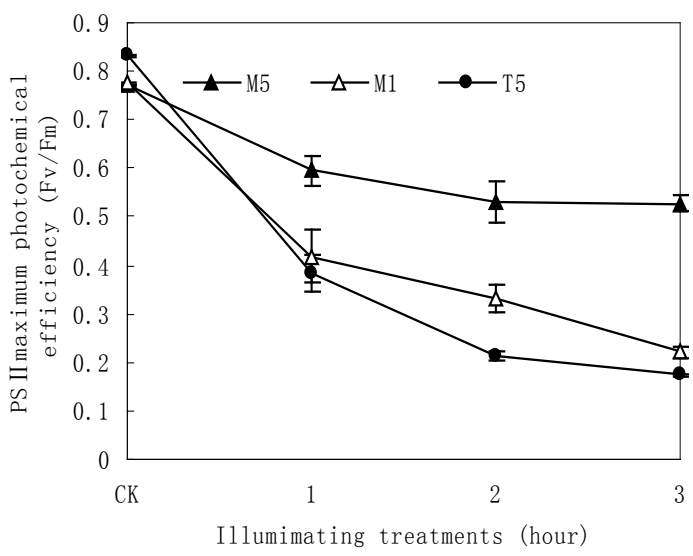

(d)

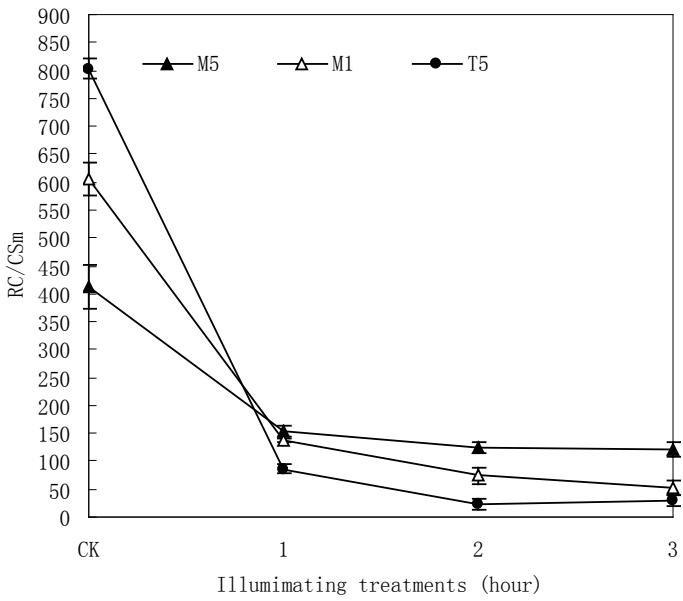

(f)

Figure 2. Changes in basic fluorescence indices in leaves with different photosynthetic characteristics during strong light and dark recovery treatments. (a) Initial fluorescence yield $\left(\mathrm{F}_{0}\right)$; (b) maximum chlorophyll fluorescence $\left(\mathrm{F}_{\mathrm{m}}\right) ;(\mathrm{c})$ difference between $\mathrm{F}_{\mathrm{m}}$ and $\mathrm{F}_{0}\left(\mathrm{~F}_{\mathrm{v}}\right) ;(\mathrm{d})$ maximum photochemical efficiency of photosystem II $\left(\mathrm{F}_{\mathrm{v}} / \mathrm{F}_{\mathrm{m}}\right)$; (e) fluorescence dissipation efficiency of light energy absorbed by photosystem II $\left(\Phi D_{0}=\mathrm{F}_{0} / \mathrm{F}_{\mathrm{m}}\right)$; (f) number of active photosystem II reaction centers per excited cross-section $\left(\mathrm{RC} / \mathrm{CS}_{\mathrm{m}}\right)$. Sample leaves were subjected to strong light $\left(2000 \mu \mathrm{mol} \cdot \mathrm{m}^{-2} \cdot \mathrm{s}^{-1}\right)$ for $3 \mathrm{~h}$ and subsequent dark recovery for $3 \mathrm{~h}$. $\boldsymbol{\Delta}$, maize fifth leaves (complete $\mathrm{C}_{4}$ cycle, M5); $\triangle$, maize first leaves (incomplete $\mathrm{C}_{4}$ cycle, $\mathrm{M} 1$ ); $\bullet$, tobacco fifth leaves $\left(\mathrm{C}_{3}\right.$ cycle, T5). Mean \pm SD of six replicates. Bars not seen are smaller than the size of the symbols. 
Fluorescence dissipation $\left(\Phi D_{0}\right)$ is $F_{0} / F_{m}$, representing the quantum yield of fluorescence dissipation of absorbed energy by harvesting pigments [16] [17]. An increase in $\Phi D_{0}$ can protect PSII against photodamage. As Figure 2(e) shows, before light treatment, $\Phi \mathrm{D}_{0}$ was 0.228 in $\mathrm{M} 5,0.225$ in M1, and 0.168 in T5. Under strong light stress, $\Phi \mathrm{D}_{0}$ increased at different scales in the three types of leaves. The $\Phi \mathrm{D}_{0}$ of M5, M1, and T5 increased by $107.15 \%, 245.71 \%$ and $391.29 \%$, respectively. The increase under strong light was less sharp in $\mathrm{C}_{4}$ leaves (M5) than in incomplete $\mathrm{C}_{4}$ leaves (M1) and $\mathrm{C}_{3}$ leaves (T5). However, the increases in $\Phi \mathrm{D}_{0}$ were caused by a reduction in $\mathrm{F}_{\mathrm{m}}$, not by an increase in $\mathrm{F}_{0}$, because $\mathrm{F}_{0}$ declined under strong light. This result suggested that $\Phi \mathrm{D}_{0}$ did not play a role in avoiding excess excitation energy accumulation in PSII under strong light in this experiment.

\section{5. $\mathrm{RC} / \mathrm{CS}_{\mathrm{m}}$}

$\mathrm{RC} / \mathrm{CS}_{\mathrm{m}}$ is the number of active PSII RC per excited cross-section, reflecting the inactivation state of PSII RC. The three types of leaves showed different levels of $\mathrm{RC} / \mathrm{CS}_{\mathrm{m}}$ under control light, and all values declined dramatically, but at different scales, under strong light (Figure 2(f)). Under strong light, $\mathrm{RC} / \mathrm{CS}_{\mathrm{m}}$ in $\mathrm{M} 5 \mathrm{de}-$ creased from 411.25 to 122.28 (by 62.76\%), in M1 from 605.31 to 52.50 (by $77.38 \%$ ), and in T5 from 803.37 to 29.41 (by $89.34 \%$ ). The decline of $\mathrm{RC} / \mathrm{CS}_{\mathrm{m}}$ indicated that a number of RC were inactivated by excess excitation energy. In comparison, $\mathrm{C}_{4}$ leaves (M5) had less active $\mathrm{RC}$ under control light but maintained more active RC under strong light than the incomplete $\mathrm{C}_{4}$ leaves (M1) and $\mathrm{C}_{3}$ leaves (T5).

\section{Discussions}

The light energy absorbed by leaves is mainly used to drive the photosynthetic carbon reduction cycle. Therefore, surplus energy is generated if carbon reduction is impeded or if light energy absorbed by leaves exceeds that consumed by carbon reduction. The resulting excess energy will lead to photoinhibition, that is, it impairs the photosynthetic apparatus and reduces the photosynthesis rate [1]. The amount of excess energy is related to photosynthetic efficiency. Under the same light intensity, leaves of $\mathrm{C}_{4}$ plants photosynthesize more efficiently than leaves of $\mathrm{C}_{3}$ plants, which means that more absorbed light energy flows into the carbon cycle and less excess energy is produced [10]. As a result, $\mathrm{C}_{4}$ leaves will be less inhibited by strong light than $\mathrm{C}_{3}$ leaves. In this study, under control light intensity, the $\mathrm{C}_{4}$ leaves (M5) had the highest rate of photosynthesis, followed by leaves with an incomplete $\mathrm{C}_{4}$ cycle (M1) and $\mathrm{C}_{3}$ leaves (T5). Although photoinhibition occurred in all types of leaves under strong light, M5 leaves were more tolerant than M1 and T5 leaves. This result showed that the photosynthetic rate underlies photoinhibition defense in plants.

Photorespiration is a carbon oxidation cycle that consumes light energy like carbon reduction pathways [18]. Increased photorespiration rates have been observed under drought [19], high temperature [20], and strong light stress [9] and 
are regarded as an important mechanism to prevent photoinhibition. In the present study, a decline in photosynthesis occurred in all types of leaves at the end of the light treatment, but the levels of decline in M1 and T5 were greater than in M5, and their photorespiration rates and the ratio of photorespiration to gross photosynthesis were much higher than those in M5. These results suggested that photorespiration played a larger role in photoinhibition defense in M1 and T5 leaves. Although the photorespiration rates increased in M1 and T5 leaves, the total energy consumption via carbon reduction and oxidation did not increase during photoinhibition. The gross photosynthetic rates at the end of light treatment were significantly lower than at the beginning of treatment. This means that the rise in energy consumption owing to photorespiration only partially compensates for the decline caused by photosynthesis. For $\mathrm{C}_{4}$ leaves, although the photorespiration rate is very low, the $\mathrm{C}_{4}$ cycle consumes more energy than the $\mathrm{C}_{3}$ cycle and reduces the energy surplus.

$\mathrm{F}_{\mathrm{v}} / \mathrm{F}_{\mathrm{m}}$ is the photochemical reaction efficiency of PSII and can be used to describe the state of the PSII RC photodamage [17]. In this experiment, a decline in $\mathrm{F}_{\mathrm{v}} / \mathrm{F}_{\mathrm{m}}$ occurred in all types of leaves under strong light treatment, but $\mathrm{F}_{\mathrm{m}}$ decreased dramatically and $F_{0}$ reduced slowly. Because $F_{v}$ is the difference between $\mathrm{F}_{\mathrm{m}}$ and $\mathrm{F}_{0}$, the decline in $\mathrm{F}_{\mathrm{v}} / \mathrm{F}_{\mathrm{m}}$ was caused by the decrease in $\mathrm{F}_{\mathrm{m}} . \mathrm{F}_{\mathrm{v}} / \mathrm{F}_{\mathrm{m}}$ declined less in M5 than in M1 and T5. This means that M5 maintained higher energy flow into the PSII RC under strong light. Given the higher rate of photosynthesis in M5 under light treatment, the energy entering PSII RC would be used to drive carbon reduction or other biochemical reactions. Hence, the dark reaction in M5 photosynthesis made a much larger contribution to avoiding energy surplus than in M1 and T5. Thus, the carbon reduction cycle played a more pivotal role in strong-light tolerance in $\mathrm{C}_{4}$ leaves than in incomplete $\mathrm{C}_{4}$ leaves.

$\mathrm{F}_{0} / \mathrm{F}_{\mathrm{m}}\left(\Phi \mathrm{D}_{0}\right)$ indicates the ratio of fluorescence dissipation via light-harvesting pigments [16] [17]. However, the rise in $\mathrm{F}_{0} / \mathrm{F}_{\mathrm{m}}$ is not simply regarded as an increase in energy dissipation and exerting a role in photoprotection, because the ratio will rise when $\mathrm{F}_{\mathrm{m}}$ decreases, even if $\mathrm{F}_{0}$ decreases during strong light treatment and thus will not contribute to reducing excess energy. In the present study, both $\mathrm{F}_{\mathrm{m}}$ and $\mathrm{F}_{0}$ declined in all three leaf types, and $\mathrm{F}_{\mathrm{m}}$ decreased more than $\mathrm{F}_{0}$ under strong light. Consequently, $\mathrm{F}_{0} / \mathrm{F}_{\mathrm{m}}$ is not suitable to represent energy dissipation via fluorescence release under strong light.

$\mathrm{F}_{0}$ is generated during the process of transferring light energy from the light-harvesting complex IIs to the PSII RC. The variation in $\mathrm{F}_{0}$ under strong light in this experiment was inconsistent with changes under other stress conditions, such as high temperature and salt stress [21] [22], when $\mathrm{F}_{0}$ usually rises. The decline in $\mathrm{F}_{0}$ under light treatment may be owing to the dramatic decline in $\mathrm{F}_{\mathrm{m}}$, which decreased the energy flow from the light-harvesting complex IIs to PSII RC. The rise in $\mathrm{F}_{0}$ under high temperature and salinity may have resulted from conformational changes in PSII supercomplexes.

The $\mathrm{F}_{\mathrm{m}}$ decline under strong light is mainly caused by state transition. In this process, light-harvesting complex IIs dissociate from PSII RC so as to reduce the 
energy supply to the latter. Therefore, state transition is considered a pivotal mechanism to protect PSII under light stress [23] [24]. Here, we used the decline rate in $\mathrm{F}_{\mathrm{m}}$ to estimate the variation in state transition. Among the three types of leaves, $\mathrm{T} 5$ showed the highest rate of decline $(53.66 \%)$ in $\mathrm{F}_{\mathrm{m}}$, followed by $\mathrm{M} 1$ (45.97\%) and then M5 (22.96\%). Hence, we deduced that state transition was more crucial to preventing photodamage to PSII RC in $\mathrm{C}_{3}$ leaves (T5) and incomplete $\mathrm{C}_{4}$ leaves (M1) than in $\mathrm{C}_{4}$ leaves (M5).

In PSII RC, D1 proteins are extremely vulnerable to photooxidative damage [25]. Therefore, the activity of RC is very susceptible to strong light stress. In this experiment, all three leaf types showed a sharp decline in $\mathrm{RC} / \mathrm{CS}_{\mathrm{m}}$ after strong light treatment. The $\mathrm{RC} / \mathrm{CS}_{\mathrm{m}}$ of M5 decreased the least (62.76\%), followed by M1 (77.38\%) and then T5 (89.34\%). We used $\mathrm{F}_{\mathrm{v}} / \mathrm{RC}$ to analyze the variation in energy flow passing through PSII centers and found that it decreased after treatment by strong light. In control light conditions, $\mathrm{F}_{\mathrm{v}} / \mathrm{RC}$ in M5, M1, and T5 were $1.493,1.428$, and 1.403 , respectively. At the end of light treatment, M5 had the highest $\mathrm{F}_{\mathrm{v}} / \mathrm{RC}$ (1.330), followed by M1 (1.116) and T5 (0.930). These results showed that $\mathrm{RC}$ in incomplete $\mathrm{C}_{4}$ leaves in maize was susceptible to strong light, similar to $\mathrm{C}_{3}$ leaves.

\section{Conclusion}

In conclusion, $\mathrm{C}_{4}$ maize leaves, with a higher rate of photosynthesis, are more tolerant to strong light stress than incomplete $\mathrm{C}_{4}$ leaves, and their PSII RC are less susceptible to intense radiation. In photoprotection, the carbon reduction cycle has an important role in $\mathrm{C}_{4}$ leaves, while state transition is pivotal in incomplete $\mathrm{C}_{4}$ leaves. Further investigation will be required to explain the underlying mechanisms of PSII reaction center susceptibility to strong light in maize incomplete $\mathrm{C}_{4}$ leaves. Interestingly, at present some genus contains both $\mathrm{C} 3, \mathrm{C} 4$ and C3-C4 intermediate species [26] [27] [28] [29], and some genus changes from C3 to C4 in different environments [30] [31]. The studies of these materials under strong light will provide more direct adaptability differences between C3 and C4 pathway.

\section{Acknowledgements}

This work was supported by the Technology Pillar Program of Liaoning Province, China (2015103001), the Natural Science Foundation of China (31000673), the Science and Technology Development of Liaoning Province, China (2014208001), the PhD research startup foundation of Liaoning Province (201501063), the Youth Foundation of Bioscience and Biotechnology College of Shenyang Agricultural University (2015).

\section{References}

[1] Vass, I. (2011) Molecular Mechanisms of Photodamage in the Photosystem II Complex. Biochimica et Biophysica Acta (BBA)-Bioenergetics, 1817, 209-217. https://doi.org/10.1016/j.bbabio.2011.04.014 
[2] Anderson, J.M., Park, Y.I. and Chow, W.S. (1997) Photoinactivation and Photoprotection of Photosystem II in Nature. Physiologia Plantarum, 100, 214-223. https://doi.org/10.1111/j.1399-3054.1997.tb04777.x

[3] Minagawa, J. (2013) Dynamic Reorganization of Photosynthetic Supercomplexes during Environmental Acclimation of Photosynthesis. Frontiers in Plant Science, 4, 513. https://doi.org/10.3389/fpls.2013.00513

[4] Gorecka, M., Alvarez-Fernandez, R., Slattery, K., McAusland, L., Davey, P.A., Karpinski, S., Lawson, T. and Mullineaux, P.M. (2014) Abscisic Acid Signalling Determines Susceptibility of Bundle Sheath Cells to Photoinhibition in High Light-Exposed Arabidopsis Leaves. Philosophical Transactions of the Royal Society B, 3, 20130234.

[5] Wang, L.F. (2014) Physiological and Molecular Responses to Variation of Light Intensity in Rubber Tree (Hevea brasiliensis Muell. Arg.). PLoS One, 27, e89514.

[6] Edwards, E.J. and Smith, S.A. (2010) Phylogenetic Analyses Reveal the Shady History of C4 Grasses. Proceedings of the National Academy of Sciences of the USA, 107, 2532-2537. https://doi.org/10.1073/pnas.0909672107

[7] Hatch, M.D. (2002) C 4 Photosynthesis: Discovery and Resolution. Photosynthesis Research, 73, 251-256. https://doi.org/10.1023/A:1020471718805

[8] Furbank, R.T. and Foyer, C.H. (1988) $\mathrm{C}_{4}$ Plants as Valuable Model Experimental Systems for the Study of Photosynthesis. New Phytologist, 109, 265-277.

https://doi.org/10.1111/j.1469-8137.1988.tb04195.x

[9] Florez-Sarasa, I., Flexas, J., Rasmusson, A.G., Umbach, A.L., Siedow, J.N. and Ribas-Carbo, M. (2011) In Vivo Cytochrome and Alternative Pathway Respiration in Leaves of Arabidopsis thaliana Plants with Altered Alternative Oxidase under Different Light Conditions. Plant Cell \& Environment, 34, 1373-1383. https://doi.org/10.1111/j.1365-3040.2011.02337.x

[10] Goh, C.H., Ko, S.M., Koh, S., Kim, Y.J. and Bae, H.J. (2011) Photosynthesis and Environments: Photoinhibition and Repair Mechanisms in Plants. Journal of Plant Biology, 55, 1-9.

[11] Hirth, M., Dietzel, L., Steiner, S., Ludwig, R., Weidenbach, H., Pfalz, J. and Pfannschmidt, T. (2013) Photosynthetic Acclimation Responses of Maize Seedlings Grown under Artificial Laboratory Light Gradients Mimicking Natural Canopy Conditions. Frontiers in Plant Science, 4, 334. https://doi.org/10.3389/fpls.2013.00334

[12] Hong, S.S. and Xu, D.Q. (1999) Reversible Inactivation of PS II Reaction Centers and the Dissociation of LHC II from PS II Complex in Soybean Leaves. Plant Science, 147, 111-118. https://doi.org/10.1016/S0168-9452(99)00106-5

[13] Cousins, A.B., Adam, N.R., Wall, G.W., Kimball, B.A., Pinter Jr, P.J., Ottman, M.J., Leavitt, S.W. and Webber, A.N. (2003) Development of $\mathrm{C}_{4}$ Photosynthesis in Sorghum Leaves Grown under Free-Air $\mathrm{CO}_{2}$ Enrichment (FACE). Journal of Experimental Botany, 54, 1969-1975. https://doi.org/10.1093/jxb/erg197

[14] Crespo, H.M., Frean, M., Cresswell, C.F. and Tew, J. (1979) The Occurrence of Both $\mathrm{C}_{3}$ and $\mathrm{C}_{4}$ Photosynthetic Characteristics in a Single Zea mays Plant. Planta, 147, 257-263. https://doi.org/10.1007/BF00388748

[15] Ku, M.S.B., Agarie, S., Nomura, M., Fukayama, H., Tsuchida, H., Ono, K., Hirose, S., Toki, S., Miyao, M. and Matsuoka, M. (1999) High-Level Expression of Maize Phosphoenolpyruvate Carboxylase in Transgenic Rice Plants. Nature Biotechnology, 17, 76-80. https://doi.org/10.1038/5256

[16] Force, L., Critchley, C. and Van Rensen, J.J.S. (2003) New Fluorescence Parameters for Monitoring Photosynthesis in Plants. Photosynthesis Research, 78, 17-33. 
https://doi.org/10.1023/A:1026012116709

[17] Strasser, R.J., Tsimilli-Michael, M. and Srivastava, A. (2004) Analysis of the Chlorophyll a Fluorescence Transient. In: Papageorgiou, G.C. and Govindjee, Eds., Chlorophyll a Fluorescence: A Signature of Photosynthesis, Springer, New York, 321-362. https://doi.org/10.1007/978-1-4020-3218-9_12

[18] Demmig-Adams, B. and Adams III, W. (1992) Photoprotection and Other Responses of Plants to High Light Stress. Annual Review of Plant Biology, 43, 599-626. https://doi.org/10.1146/annurev.pp.43.060192.003123

[19] Guan, X.Q., Zhao, S.J., Li, D.Q. and Shu, H.R. (2004) Photoprotective Function of Photorespiration in Several Grapevine Cultivars under Drought Stress. Photosynthetica, 42, 31-36. https://doi.org/10.1023/B:PHOT.0000040566.55149.52

[20] Zhang, W., Huang, W., Yang, Q.Y., Zhang, S.B. and Hu, H. (2013) Effect of Growth Temperature on the Electron Flow for Photorespiration in Leaves of Tobacco Grown in the Field. Physiologia Plantarum, 149, 141-150. https://doi.org/10.1111/ppl.12044

[21] Janka, E., Körner, O., Rosenqvist, E. and Ottosen, C.O. (2013) High Temperature Stress Monitoring and Detection Using Chlorophyll a Fluorescence and Infrared Thermography in Chrysanthemum (Dendranthema grandiflora). Plant Physiology and Biochemistry, 67, 87-94. https://doi.org/10.1016/j.plaphy.2013.02.025

[22] Mathur, S., Mehta, P. and Jajoo, A. (2013) Effects of Dual Stress (High Salt and High Temperature) on the Photochemical Efficiency of Wheat Leaves (Triticum aestivum). Physiology and Molecular Biology of Plants, 19, 179-188. https://doi.org/10.1007/s12298-012-0151-5

[23] Dietzel, L., Bräutigam, K. and Pfannschmidt, T. (2008) Photosynthetic Acclimation: State Transitions and Adjustment of Photosystem Stoichiometry-Functional Relationships between Short-Term and Long-Term Light Quality Acclimation in Plants. The FEBS Journal, 275, 1080-1088. https://doi.org/10.1111/j.1742-4658.2008.06264.x

[24] Cui, Z., Wang, Y., Zhang, A. and Zhang, L. (2014) Regulation of Reversible Dissociation of LHCII from PSII by Phosphorylation in Plants. American Journal of Plant Sciences, 5, 241-249. https://doi.org/10.4236/ajps.2014.52032

[25] Nath, K., Jajoo, A., Poudyal, R.S., Timilsina, R., Park, Y.S., Aro, E.M., Nam, H.G. and Lee, C.H. (2013) Towards a Critical Understanding of the Photosystem II Repair Mechanism and Its Regulation during Stress Conditions. FEBS Letters, 587, 3372-3381. https://doi.org/10.1016/j.febslet.2013.09.015

[26] Stata, M., Sage, T.L., Hoffmann, N., et al. (2016) Mesophyll Chloroplast Investment in C3, C4 and C2 Species of the Genus Flaveria. Plant and Cell Physiology, 57, pcw015. https://doi.org/10.1093/pcp/pcw015

[27] Muhaidat, R., Sage, T.L., Frohlich, M.W., Dengler, N.G. and Sage, R.F. (2011) Characterization of $\mathrm{C}_{3}-\mathrm{C}_{4}$ Intermediate Species in the Genus Heliotropium L. (Boraginaceae): Anatomy, Ultrastructure and Enzyme Activity. Plant, Cell \& Environment, 34, 1723-1736.

[28] Khoshravesh, R., Hossein, A., Sage, T.L., Nordenstam, B. and Sage, R.F. (2012) Phylogeny and Photosynthetic Pathway Distribution in Anticharis Endl. (Scrophulariaceae). Journal of Experimental Botany, 63, 5645-5658. https://doi.org/10.1093/jxb/ers218

[29] Fisher, A.E., McDade, L.A., Kiel, C.A., Khoshravesh, R., Johnson, M.A., Stata, M., Sage, T.L. and Sage, R.F. (2015) Evolutionary History of Blepharis (Acanthaceae) and the Origin of C4 Photosynthesis in Section Acanthodium. International Journal of Plant Sciences, 176, 770-790. https://doi.org/10.1086/683011 
[30] Magnin, N.C., Cooley, B.A., Reiskind, J.B. and Bowes, G. (1997) Regulation and Localization of Key Enzymes during the Induction of Kranz-Less, C4-Type Photosynthesis in Hydrilla verticillata. Plant Physiology, 115, 1681-1689. https://doi.org/10.1104/pp.115.4.1681

[31] Ueno, O., Samejima, M., Muto, S. and Miyachi, S. (1988) Photosynthetic Characteristics of an Amphibious Plant, Eleocharis vivipara: Expression of C4 and C3 Modes in Contrasting Environments. Proceedings of the National Academy of Sciences, 85, 6733-6737. https://doi.org/10.1073/pnas.85.18.6733

Submit or recommend next manuscript to SCIRP and we will provide best service for you:

Accepting pre-submission inquiries through Email, Facebook, LinkedIn, Twitter, etc. A wide selection of journals (inclusive of 9 subjects, more than 200 journals)

Providing 24-hour high-quality service

User-friendly online submission system

Fair and swift peer-review system

Efficient typesetting and proofreading procedure

Display of the result of downloads and visits, as well as the number of cited articles Maximum dissemination of your research work

Submit your manuscript at: http://papersubmission.scirp.org/

Or contact ajps@scirp.org 